\title{
REGISTRATION OF VOTERS WITHIN THE PERSPECTIVE OF CONSTITUTIONAL DEMOCRACY: CASE STUDY OF REGISTER OF VOTERS IN 2014 GENERAL ELECTION
}

\author{
Zainal Arifin Hoesein. \\ Constituional Court of The Republik of Indonesia \\ Email: arifinhoesein55@yahoo.com
}

\begin{abstract}
Voting right is citizen's constitutional rights. There is nothing that can obscure it, not to mention negate it, as long as it is not against the moral, religious, public stability and security values. The action to negate the voting rights is an act of dismissal of democratic constitutional values. Indeed, the democratic values strongly upheld the citizens' rights, including the voting rights. The correlation between the voting rights and the general election administration is a synergic correlation to create conducive election as mandated by the constitution. Administration role should not have been an obstacle for upholding the constitutional democratic values, rather, it becomes a filter in regulating each citizen in using their voting rights to ensure the legal certainty, either from technical aspects, which is the accurate ballot counting, or from substantive aspect that is to ensure the legal certainty in conducting the accountable general election. In deciding the voters, several things should be prioritized such as first, the administrative management of general election related to the population administration; and, second, the voting rights transformed into the List of Fixed Voters (DPT). Administrative data of population is a baseline data and the data source for establishing the List of Fixed Voters (DPT).
\end{abstract}

Keywords: Constitutional democracy, general election, voters' administration, and rights, the list of fixed voter.

\section{A. INTRODUCTION}

The principle of independence is the freedom to decide their own fate and rights without any restriction to reach their dreams. The independent population is those whom that within their own power and ability develop and direct their efforts to attain social welfare as their ultimate goal. There are many capital and model of government to become a governance system for the people to bring them to achieve their welfare, whether it is a monarchy, aristocracy, or democracy. The challenge of time and the advancement of knowledge and technology on the state has brought the law scholars' thought to the conclusion that there is no longer better means in implementing the government system 
that can bring forward the welfare of the society other than people's government system or democracy. Democratic government system has become the single mean believed by many countries to attain welfare (Harbison dan Mayers, 1964:133). Thus, the government headed by King /Rex (Hart, 2013:82) has started to be left, such as, things that are happening in Asia and Middle East where their governance systems are switching to a democratic system.

A democratic governance model that becomes the focus of attaining prosperity for the people is the main object of investigation for the academics. It is a well-accepted concept today that the formulation and concept of democracy are constantly evolving. The combination between the democratic state principles and the law state ( $\underline{\text { Schmid, 1988:11) }}$ has become an ideal collaboration to systemize the people's power by law, and in order to avoid certain group's dominance on the name of people's power. This is the basic for the later developed concept of constitutional democracy.

The constitutional democratic state would see that people have the ultimate power, however, the implementation is conducted in a firm and well-managed system, and the implementation is not centered in certain power formulated within the constitution. The nature of the constitutional democratic state is that the ideas of democratic governance are governance system with limited power and injustice treatments toward the citizens are strongly forbidden (Budiarjo, 2008:107). The limit of the government power is mentioned in the constitution; therefore, it is often called as constitutional government. Thus, constitutional government is similar to limited government or restrained government. (Budiarjo, 2008:107).

Constitution is a document contains regulation on how an organization (a state) is operated (Thompson, 1997:3). In the same sense, a state generally has the document called constitution (Phillips, 1987:5). The importance of constitution as an instrument of a state operation also influences the model of people power implementation in Indonesia. UUD 1945 as the constitution for the Indonesian people is a legal document as well as the political document that contains the objectives, the foundations, and the principles of this state's life (Barendt, 1988: 2-7), including stipulation on General Election (Pemilu) (UUD 1945) as means of citizens' political rights. Indonesia as people sovereign state as stipulated in Article 1 Clause (2) of UUD 1945 placed its citizens as the owner of the 
sovereign power. Therefore, Indonesian citizens have rights to decide who will work to manage the state business. That ultimate right is the right to elect in the General Election (Pemilu) (UUD 1945). It is strongly prohibited to neglect each citizen's right to vote, considering that each citizen are an integral part of the people who hold the sovereign power upon this state. Acknowledgment of each citizen's right to vote is stated in Article 27 clause (1) of UUD 1945, which stated that each citizen has the same position before the law and government and has to uphold that law and government with no exception. The assurance on the citizens right to vote in Article 27 Clause (1) of UUD 1945 is a proof that the citizens' right to vote to have to be upheld and protected by the state. Thus, the negligence act on citizens' vote right can be assumed as a crime toward human rights.

In assuring the equality and fairness of the citizens as part of the constitutional demo cratic principles, voting rights of the citizens in the general election toward the process of registering voters can be ensured for every citizens have been fully accommodated without discrimination of Ethnicity, Race, Religion, and Groups nor it is just merely a formal aspect. This assurance is important regarding to the registration of voters is one of the parameters for level of democracy within a state that applies the people's government system. The least the voters that are not registered in the voters' registry, the highest the value of democracy, and vice versa.

An effort ensures citizens on their voting rights can be done through providing a factual and valid voters' registry. Factual voters' registry is registering the voters using the up to date data, and including all the voters that are eligible to vote. Meanwhile, valid voters registry is registering voters using the exact and valid, and verified numbers of eligible voters. It means that there are no marginalized groups or individuals that are not registered in the voters' registry.

As in the cases that had happened in Indonesian general elections, there were citizens rights to vote that are still neglected, especially during the New Order Regime. There are a few groups of people with marginalized political rights, due to their political affiliation in the past. The marginalized group mentioned above is the ex-PKI (Indonesian Communist Party) who have no rights to vote. This treatment was started from the previous regime. During the Soekarno reign, an Act No. 27 of 1948 on House of Representatives and Election of Its Members was passed on. That act stipulated that only 
those who are literate that can use their voting rights in 1955 General Election. The qualification in that Act No. 28 of 1948 is one of the forms of reduction of the democratic values within a constitutional democratic state.

Up to the last election in 2014 General Election in electing the members of parliaments and president and vice presidents, the practices that undermine the democratic values were still practiced. The problem in 2014 General Election was that there was a group of eligible voters that were not registered in the voters' registry. There were also citizens with no citizen's identity cards (KTP) and it made them ineligible to vote. In addition, there were also others problems that indicate the practices of undermining the value of democracy, such as, voters' registry with underage children or eligible voters that have already passed away. These conditions have made the implementation of the general election to be less democratic than what is expected by the UUD 1945, and pragmatically, it lead to the low credibility and integrity of the elected parliament members, president, and vice presidents.

In relation to the problem stated above, there are two problem statements formulated on voters' registry dominating the 2014 General: First, administrative governance of General Election related to the population administration. Population administration is the responsibility of the government especially the Ministry of Domestic Affairs, this is considered as contributory to the voters' registry problem. For a state as big as Indonesia, as the fourth country with the biggest population on earth after China, India, and the US, population administration problem need a comprehensive effort to overcome it. Otherwise, it would cause chaos in population data, because citizens can have more than one Identity Card, or they can have fake Identity Card. (adminduk.kemendagri, 2015) Moreover, there are citizens that do not have identity card due to the mismanagement of population administration. This is a serious problem that contributes to the establishment of voters' registry in General Election. Within the population administration management before the President and Vice President Election in 2014, this problem had not been properly resolved. For instance, in Jawa Tengah province, thousands of ineligible voters were listed in the temporary voters' registry. The final update of voters included in this category were those who had died 15,863 people, mentally disabled 212 people, under 17 and unmarried 356 people, changed address 15,164 people, Members of the Army officers 93 people, and Police officers 104. In reverse, the young voters that 
should be eligible to vote were not registered within the voter's registry. The final update of the 17 years old voters were 20,345; under 17 and had married were 3,624; retired army officers were 142, and retired police officers were 71 people. In addition, there were thousands of mistakes in the written data of the voters, such as, mistakes in the number of family card were 16,897; mistakes in the ID number were 3.523 ; name mistakes were 797 ; mistakes in place and date of birth were 579; mistakes in marital status were 4;410; mistakes in sex were 387 ; and mistakes in writing the address were 2;610 (politik.news viva, 2015).

Second, the citizens right to vote which was transformed into the form of the list of fixed voters (DPT). The problem in this DPT was that there were very large numbers of voters that were not listed in this DPT. This incident had made the voters lost their rights to vote. The election committee (KPU) as the election administrator has made the instrument for the list of special voters (DPK), and a list of additional special voters (DPKTb) to back up the citizens that were not listed within the DPT. It was noted that in the big area such as Sumatera Barat, there were 67,607 out of 2,354,327 voters who used their identity card (KTP) or other identification listed within the DPKTb. This number is equal to $2.8 \%$ of the total voters who used their voting rights in 2014 presidential election. Meanwhile, in Jawa Tengah, the voters who used the KTP or other identification (DPKTb) were 156,798 out of $19,668,404$ voters who used their voting rights in the 2014presidential election or $0.79 \%$ of the total voters who used their voting rights (Isra, 2014). ${ }^{1}$. this has drawn attention that cannot be ignored, because if the administration is failed, then the construction of the people's sovereignty is no longer pure. In addition to that, neglecting the people's right is an incredible crime that can potentially destroy the nation's foundation.

Prabowo-Hatta as the candidate who competed in the 2014 presidential election and their team had found many citizens who were not listed within the DPT and then migrated to DPK and DPKTb. DPK and DPKTb were considered by Prabowo-Hatta and his team as another form of DPT, which according to them is undesirable by the Law. Because within the Law No. 42 of 2008 on Presidential and Vice Presidential Election, the term $\mathrm{DPKTb}$ is unrecognizable. Thus, the formulation of DPKTb is considered marring the 
democratic value and is something incredible. To solve the problem, the Prabowo-Hatta team proceed to Constitutional Court (MK) as stipulated by the Article $24 \mathrm{C}$ clause (1) of UUD 1945 that the MK is the judicial body who has the power to settle the disputes of election result (UUD 1945). MK as the final interpreter of the UUD 1945 is ensured to support the existence of the citizens' voting rights as the form and tool to implement the people's sovereignty. The reflection of the MK's support toward the citizens' voting right is seen in their idea on the importance of the citizens' voting rights as stipulated in MK's decree No. 102/PUU-VII/2009 on the assessment of Law No. 42 of 2008 on Presidential and Vice Presidential Election. In this decree, MK states: " that the citizens' rights to vote as described above has been stipulated as human rights and constitutional rights of the citizen therefore, that constitutional rights cannot be prohibited or banned by any regulation and administrative procedure that inhibit the citizens to use their voting rights". Therefore, constitutionally, the citizens' voting rights is a very important rights and is enhanced its protection by the state.

From the above description of the reality within the establishment of the election in Indonesia, the author would like to analyze registration of voters in the implementation of election post reformation era within the perspective of constitutional democracy. In this writing, the author would like to insist that currently there are many scholars in law that have tried to discuss and tried to find the solution of the election problem within the limit of the election participants, election system, election organization and election ethics. However, there were only very few researches who discussed the establishment or registration of voters within the perspective of constitutional democracy. Regardless to the fact that the most important thing in a general election is the votes as the subject of the election, hence, the establishment or registration of voters becomes important. Therefore, this research is expected to propose some answer and to formulate the solution related to registration of voters according to the principles of fairness and integrity in the implementation of the general election. This research is titled, "Register of Voters within the Perspective of Constitutional Democracy".

\section{B. PROBLEM STATEMENT}

Along with the theme discussed above, this research would be focused on how was the registration of voters within the perspective of constitutional democracy? 


\section{RESEARCH METHOD}

In this approach, the secondary data such as documents or literature is thoroughly researched to collect information on laws and regulation, written data, books, seminar results, research output, and other references, and data and information through websites related to the problem discussed in this research.

The secondary data collected to be analysed consists of:

a. Legal primary sources such as law and regulation, and legal documents related to election;

b. A legal secondary source such as books, research output, papers, and articles from the legal experts.

c. A legal tertiary source such as legal dictionary, encyclopedia, and other information related to the registration of voters in implementing the people sovereignty.

The secondary data then analyzed qualitatively to be presented for the making the final conclusion. The conclusion would be made using the deductive technique, in which one finding the lead to generalization of a problem.

\section{DISCUSSION}

\section{Citizens' voting right}

The political right is a privilege to influence the objectives of a state. It means that individual directly or indirectly participates in developing the legal government in which the state's will is revealed (Kelsen, 2013:157). Political right as the individual right of each individual is protected by the either international law or constitutional law that claimed as the basic of the democratic state.

Indonesia as a constitutional state is a state that upholds the human rights. Human rights could be generally defined as those rights which are inherent in our nature and without which we cannot live as human beings (United Nation, 1993). Indonesia regulates the 
human rights within its constitution, the Undang-Undang Dasar 1945 (UUD 1945), as other states in the world are (Purbopranoto, 1979:64). The view on human rights is not only important in Indonesia. The concept of international law also protected human rights to vote. One of them is the International Covenant on Civil and Political Rights (ICCPR 1966). ICCPR 1966 regulates the political rights in participating in an election. This rights is regulated in Article 25 which stated that, "Each citizen has to have equal right and chance without any discrimination as mentioned in Article 2 of ICCPR and without any illegal confinement to participate in implementing any general business directly or through representatives that were freely elected and with equal and universal voting rights and conducted through written and confidential vote that ensure each voters to freely voiced their rights, and to obtain general services in their own country and in any other country on the basis of quality. The stipulation above is aimed to insist that the voting rights is indeed human rights. Any confinement, limitation, negligence, and eradication of that right is a form of violation of the citizens' right.

The management of the human rights in Indonesia is established under the state's responsibility. Therefore, Indonesia is responsible for making a concept of implementation in ensuring the fulfillment of its citizens' rights (Wiratraman, 2005). The state obligation, especially the government, is to ensure the freedom condition for the citizens to participate in the election, including if there is a legal problem, whether it is administrative problem or other legal violation. Human rights have to be viewed as something essential within the context of the general election, it is not only related to voting or giving their vote, but the election itself has to be conducted according to the human rights requirement (KomnasHAM, 2015).

Vulnerable groups on the negligence of their rights by the state are groups that should be the indicator for the state to ensure the fulfillment of their rights in general election (KomnasHAM, 2014). Availability of rooms to limit the rights attached to each person and Indonesian citizens have created the arrangement that the voting rights are possible to not being attached to every Indonesian citizen. It means, that the voting rights are limited by the state, nevertheless, the state is not directly limiting this right without considering that the voting rights are part of the democratic principles and as part of the human rights that have to be fulfilled and ensured its fulfillment by the state. 
2. Voting rights and general election administration

The voting rights are categorized into a public affair, therefore, its discussion becomes the focus of "state administration law" (Lembaga Administrasi Negara Republik Indonesia, 2003:2). Strong in his book, Modern political Constitutions, states that "The Modern Of Constitution "Administrative law, says one, is the body of rules which regulate the relations of the administrative authority towards private citizens, and determines the position of state officials, the right and liabilities of private citizens in their dealings with these official as representatives of the state and the procedure by which these rights and liabilities enforced (Strong, 1972:254). Strong's view on administration law is that administration law as an instrument that will regulate human in their status as citizens, on their rights and responsibilities, the state position toward its citizens, etc.

Administration role in the lives of the people, the state, and the nation in the modern era is a reality that cannot be negated. The importance of the state administration some are due to the organized pattern of lives within the pattern of the modern lives, in which, people think and cooperate rationally. In addition to that, this pattern of lives also requires knowledge and modern technology, and modern way of thinking and cooperate rationally in order to achieve effective and efficient administration for the ultimate purpose of the state (Strong, 1972:254).

The objective of a state is not separated from the objective of the coexistence of its citizens to achieve the social welfare in every level of social, economic, political, security, fairness, and equality state of life, or for the betterment of the public interest. The process of the state objective that involves government and the society is conducted through the state administration system that determines certain position and roles, either the government officials or its citizens and the relationship pattern between those two.

The implementation of state administration in administering the rights of its citizens is conducted through the rules and regulation, including the regulation on the rights to vote. Administration of general election indeed is aimed to give protection and acknowledgment toward the personal status and the legal status of the Indonesian 
citizens that reside within and or outside the jurisdiction of the United Republic of Indonesia (NKRI).

The administration also becomes a filter in regulating and determining each citizen in using their voting rights. Selectiveness also applies in filtering and deciding which citizens that can use their voting rights. In personal maturity, it was determined that those who come to age (at least 17 to 21 years) or more are those who are eligible to vote. In reverse, each citizen that have not come to age of 17 , they are not eligible to use their voting rights, even though they are legal citizens

MK through adjudication No. 102/PUU-VII/2009 stated that general election administration cannot inhibit the constitutional rights of its citizens in giving their vote. The MK decree has made and stipulated that the voters that were not registered in the DPT are allowed to use their KTP or other reliable Ids. Therefore, even though, MK ignored the administration, it still stipulated the using of other reliable Ids and using the voting rights in specific time. This proves that implementation of the state is not separated from an administration. The state cannot just ignore administrative requirements and put forward the rights of the citizens without involving administration that function as the regulator and the protector. MK also stipulated that administration should be implemented as long as it is based on the sound reasons, rational and proportional. That limitation is only implemented with the sole purpose of "ensuring the acknowledgment on the respect for the rights and freedom of others to fulfill the fair demand based on the moral, and religious, security, and stability consideration within a democratic society. Hence, the general election administration is possible to be limited, but as much as possible minimize the regulation that limits the limitation and at the same time not ignoring the certainty of the result general election implementation. The correlation of the voting rights and the general election administration is a synergic relationship to achieve general election with integrity and accountable general election.

Correlation of voting rights and the general election is the relationship where administration functions as a filter in regulating and determining each citizen in using their voting rights. Every implementation of the election has a different qualification in their own time; depend on the situation and understanding of the stakeholders at that time. Voters' registry is categorized upon the level of knowledge and role of the state in 
implementing the filters toward the citizens that are eligible to use their voting rights. The relationship between the voting rights and the administration of general election is a synergic relationship to ensure, either from a technical aspect, which is the accurate result of ballot calculation or from a substantive aspect that is to ensure the overall quality of the general election implementation. A well-managed administration system can lead to an accountable the election and election that possibly create the fair and just election. The highest involvement of the state in the implementation of the general election cannot be held accountable for good integrity unless it goes hand in hand with the administrative roles. Because the current modern community demands everything to be based on facts and accurate data that can be held accountable in wider stakeholders. In the event where accurate data and facts are not available, the implementation of the general election would have low quality and incredible. Nevertheless, the administrative role in administering the general election cannot have bureaucratization, because bureaucratization is a forced way to implement the excessive law and regulation that would eventually create a barrier for the implementation of constitutional democracy (Apter, 1987:465).

\section{Voters registry in general election}

The general election is implemented by obliging the principles of the election stipulated in UUD 1945 and international standard of the election. Indonesia election principles are written in Article 22E Clause (1) UUD 1945 that consists of the direct principle, general principle, free principle, confidential principle, honest principle, and fair principle conducted once in five years (Bawaslu, 2009:1-2). 2 Meanwhile, the international standard of the election is many declarations, and international convention, regional conventions, and Declaration and United Nations Convention on Human Rights and other related legal documents. Some of the legal basis of the protection of the voting rights are mentioned in a) Universal Declaration on Human Rights in 1948 b) international treaty on civil and political rights in 1960; c) European Convention in 1950 (together with its protocol) on protection of human rights and freedom of rights; d) Document on Copenhagen Meeting in 1990 from the Conference of Human Dimension on the conference Security and Cooperation in Europe (CSCE); e) American declaration 
in 1948 on Human Rights and Duties; f) American convention in 1969 on Human Rights; and g) African Charter in 1981 on Human and Community Rights (International IDEA, 2002:7).

The election principle in UUD 1945 and the international standard of the general election are both putting forward the citizens right to participate in the election, both to elect and to be elected. Implementation of general election respects and puts forward the rights of the citizens to elect and to be elected without any discrimination, either racial discrimination or anything that negated human rights in the election, and that is the ultimate goal would like to be achieved by implementing the general election principles according to the UUD 1945 and the international standard of general election.

The main work in producing an election that upheld the election principles mentioned in UUD 1945 and meet the international standard of general election is voters' registry. Even though it is not firmly mentioned, the implicit values is that in the process of election the main thing is about the voters' registry. Because, in principles between the election principles in UUD 1945 and the international standard of election are both trying to make the citizens voting rights respected and fulfilled to participate in the election. In the voters' registry, the institution that administers the election is required to be able to construct and to formulate the accurate voters data, without any abstractions that obstruct and negate the voting rights of the citizens. One of the instruments that owns and determines the important role in the implementation of the election is the voters. Voters is the subject in the elation that becomes the focus in measuring the quality of a democratic election. In an election administration system, voters are constructed in a registry called List of Voters Registry (DPT). DPT is none but an administrative construct of voters registration as main process toward the next process, that is the implementation of voting for legislative members and presidential and vice presidential election. The DPT provide facilities to the citizens to be registered within the DPT. This is a wise act to massively registered the citizens who have the voting rights in the election. In the United States and many other democratic countries, in 1993, they have made it easier for the citizens to use their voting rights by allowing the citizens to registered their voting rights when they renewed their driving license (Biro Program Informasi Internasional, 2012:68). 
Constitutional democratic voters registry has to accommodate citizens to have their voting rights and doing it fairly and at the same time doing it based on the principles of election within the constitution and international regulation on a general election. Voters registry as proposed by Hans Kelsen in his book General Theory on Law and State can be classified as follow (Kelsen, 2013:413): 1. Universality; 2. As just as possible; 3. As much as possible minimizing the chance of abandoning individuals rights to vote; 4. Minimum age limit to vote is as early as possible; 5. No discrimination against any individuals; 6. One man one vote. The above description of the requirement of democratic voters registry can be further explained as follow:

a. Universality means that each requirements stipulated within the construct of voters' registry are according to the general standard of voters registry, and according to the ideal standard of voters registry internationally. For instance, the voters' registry that included the citizenship status or establishment of minimum age limit.

b. As far as possible means that voters registry should uphold equality among voters without any discriminative essence in its establishment;

c. As much as possible trying to include all people who have rights to vote means giving chance to all eligible citizens to use their voting rights without any racial discrimination, religious discrimination, political discrimination, etc.;

d. Minimum age limit means that voters registry should as much as possible include all the citizens as voters. Minimum age limit means that the international standard for someone to be considered an adult to be involved in an election. For instance, the average standard for voters registry is 17-20 years old, or citizens under 17 who have married also eligible to vote;

e. One man one vote means that every voter have the same value of vote as others, that all voter are equal and are given equal rights in the election process. The trending term for it now is One Man, One Vote, One Value (OVOV).

4. Legal construction of voters' registry

a. Legal construction of voters registry in 1999 general election 
In the first election post, the Soeharto Regime is implemented based on Law No. 3 of 1999 on General Election, Election is conducted with new ideas, however, the voters registry did not experienced expected changes.

Voters' registry in 1999 was conducted based on the Law No. 3 of 1999 about General Election. In this election, citizens who are eligible to vote are mandatory to do several things. In general, citizens who are eligible to vote are those who have reached the age of 17 or those under 17 who are/have married. Nevertheless, there are specific criteria to be eligible to vote are:

a. Evidently not mentally disabled/their memory is not disturbed;

b. Currently not serving any sentence based on the court decree who have an enforceable right on offense with more than 5 years penalty;

c. Those whose voting rights are not taken away by the court decree who already have enforceable right.

Analysis and assessment of the legal construction of voters registry within the perspective of people sovereignty in 1999 general election can be seen in the following table:

\section{Table 1: Voters registry in 1999 general election}

\begin{tabular}{|c|c|c|c|}
\hline $\begin{array}{l}\text { Voters } \\
\text { Registry }\end{array}$ & Analysis & Notes & Conclusion \\
\hline $\begin{array}{l}\text { Indonesian } \\
\text { Citizens }\end{array}$ & $\begin{array}{l}\text { Citizenship status considered as the } \\
\text { criteria for one to be eligible to vote } \\
\text { is a general requirement and is } \\
\text { applicable in other democratic } \\
\text { states. }\end{array}$ & $\begin{array}{l}\text { Is something } \\
\text { universal, and is } \\
\text { not against the } \\
\text { criteria of voters } \\
\text { registry in } \\
\text { people's sovereign } \\
\text { states }\end{array}$ & \\
\hline $\begin{array}{l}\text { Age } \\
\text { 17/married; }\end{array}$ & $\begin{array}{l}\text { Age limit and marriage status } \\
\text { decided as the requirement to be } \\
\text { eligible to vote is a general and } \\
\text { universally applicable. This }\end{array}$ & $\begin{array}{l}\text { Is something } \\
\text { universal, and is } \\
\text { not against the } \\
\text { criteria of voters' }\end{array}$ & \\
\hline
\end{tabular}




\begin{tabular}{|c|c|c|c|}
\hline & $\begin{array}{l}\text { requirement is a consideration of } \\
\text { citizens' maturity to elect their } \\
\text { leaders/representatives. }\end{array}$ & $\begin{array}{l}\text { registry in } \\
\text { people's sovereign } \\
\text { states. }\end{array}$ & \\
\hline $\begin{array}{l}\text { Not } \\
\text { mentally } \\
\text { disabled, } \\
\text { and }\end{array}$ & $\begin{array}{l}\text { Each citizen who are eligible to } \\
\text { vote, also bear responsibility for } \\
\text { his/her choice. It would be hard to } \\
\text { held mentally disabled person's } \\
\text { accountable for what she/he has } \\
\text { done. Thus, exception for those } \\
\text { who are mentally disabled to vote is } \\
\text { universally acceptable and it is also } \\
\text { supported by legal logic. }\end{array}$ & $\begin{array}{l}\text { Is something } \\
\text { universal, and is } \\
\text { not against the } \\
\text { criteria of people's } \\
\text { sovereign voters } \\
\text { registry }\end{array}$ & $\begin{array}{l}\text { "voters' } \\
\text { registry that } \\
\text { does not } \\
\text { reflect the } \\
\text { constitutional }\end{array}$ \\
\hline $\begin{array}{l}\text { Currently } \\
\text { not serving } \\
\text { sentence } \\
\text { with more } \\
\text { than } 5 \\
\text { years } \\
\text { penalty }\end{array}$ & $\begin{array}{l}\text { As long as one is still holding } \\
\text { his/her citizenship status, the rights } \\
\text { and responsibility is appertained to } \\
\text { that citizenship. Those who are } \\
\text { serving their time in jail is } \\
\text { considered eligible to vote, unless } \\
\text { the court ruled otherwise. This is } \\
\text { based on the fairness and equality } \\
\text { values among citizens. }\end{array}$ & $\begin{array}{l}\text { Regulation on } \\
\text { individuals' } \\
\text { exception of } \\
\text { voters' registry is } \\
\text { against the } \\
\text { universal and } \\
\text { fairness values. }\end{array}$ & democracy" \\
\hline $\begin{array}{l}\text { Voting } \\
\text { rights are } \\
\text { not } \\
\text { revoked; }\end{array}$ & $\begin{array}{l}\text { Rights can only be implemented } \\
\text { when it is not against the law. } \\
\text { Annulment of rights can only be } \\
\text { done by the court as judicial } \\
\text { institution that is allowed to give } \\
\text { injunction toward legal } \\
\text { implementation, including the rights } \\
\text { of the citizens and its annulment. } \\
\text { Thus, exception toward the citizens } \\
\text { that are already sentenced and } \\
\text { revoked their voting rights is } \\
\text { something based on the legal logic }\end{array}$ & $\begin{array}{l}\text { Is something } \\
\text { universal, and is } \\
\text { not against the } \\
\text { criteria of voters' } \\
\text { registry in } \\
\text { people's sovereign } \\
\text { states. }\end{array}$ & \\
\hline
\end{tabular}




\begin{tabular}{|l|l|l|}
\hline \multicolumn{3}{|l|}{ and constitutional democracy. } \\
\hline Registered & Each citizen has equal rights and & Regulation on \\
in the & value in election process. & voters registry \\
voters, & Exempting citizens from voting due & that exempted \\
registry; & to administrative things is individuals is \\
& something ridiculous, because it against the \\
& brings possibility for neglecting the & universal rights \\
& substantive rights of the citizens. & and fairness value. \\
\hline
\end{tabular}

\section{b. Legal construction of voters' registry in 2004 general election}

2004 General Election actually was backed up by four laws, namely, Law No. 4 of 2000 on Amendment of Law No. 3 of 1999 on General Election, Law No. 23 of 2003 on Presidential and Vice Presidential Election, Law No. 12 of 2003 on Election of Members of National Parliament, Regionals' Representative, and Regional Parliament Members, and Law No. 20 of 2004 on Establishment of Government Regulation as the Substitute of Law No. 2 of 2004 on Amendment of Law No. 12 of 2003 on Election of Members of National Parliament, Regionals' Representative, and Regional Parliament Members. However, in the regulation on voters' registry is regulated in Indonesian Law No. 12 of 2003 on Election of Members of National Parliament, Regionals' Representative, and Regional Parliament Members.

Just as the previous elections, voters are Republic Indonesian citizens aged at least 17 years old at the day of the election or below 17 but are or was married are eligible as voters. For the citizens to be listed as voters should fulfilled the below criteria:

a. Apparent not to be mentally disabled;

b. Currently not revoked of his/her voting rights based on the court injunction who has already have enforceable rights.

Based on the voters registry described above, there is difference with previous election, where those who are currently serving their sentence; and those who are currently lost their freedom according to the law (revoked of their voting rights); unlisted in the voting registry are those who cannot use their voting rights. 
The analysis of assessment toward the legal construction of voters' registry in the perspective of people's sovereignty in voters' registry in 2004 election can be seen in the following table:

\section{Table 2: Voters registry in 2004 election}

\begin{tabular}{|c|c|c|c|}
\hline $\begin{array}{l}\text { Voters' } \\
\text { Registry }\end{array}$ & Analysis & Notes & Conclusion \\
\hline $\begin{array}{l}\text { Indonesian } \\
\text { Citizens }\end{array}$ & $\begin{array}{l}\text { Citizenship status considered as the } \\
\text { criteria for one to be eligible to vote } \\
\text { is a general requirement and is } \\
\text { applicable in other democratic states. }\end{array}$ & $\begin{array}{l}\text { Is something } \\
\text { universal, and is } \\
\text { not against the } \\
\text { criteria of voters' } \\
\text { registry in a } \\
\text { people's } \\
\text { sovereign states. }\end{array}$ & \\
\hline $\begin{array}{l}\text { Age } \\
\text { 17/Married; }\end{array}$ & $\begin{array}{l}\text { Age limit and marriage status } \\
\text { decided as the requirement to be } \\
\text { eligible to vote is a general and } \\
\text { universally applicable. This } \\
\text { requirement is a consideration of } \\
\text { citizens' maturity to elect their } \\
\text { leaders/representatives }\end{array}$ & $\begin{array}{l}\text { Is something } \\
\text { universal, and is } \\
\text { not against the } \\
\text { criteria of voters' } \\
\text { registry in } \\
\text { people's } \\
\text { sovereign states. }\end{array}$ & \\
\hline $\begin{array}{l}\text { Not } \\
\text { Mentally } \\
\text { Disabled }\end{array}$ & $\begin{array}{l}\text { Each citizen who are eligible to vote, } \\
\text { also bear responsibility for his/her } \\
\text { choice. It would be hard to held } \\
\text { mentally disabled person's } \\
\text { accountable for what she/he has } \\
\text { done. Thus, exception for those who } \\
\text { are mentally disabled to vote is } \\
\text { universally acceptable and it is also } \\
\text { supported by legal logic. }\end{array}$ & $\begin{array}{l}\text { Is something } \\
\text { universal, and is } \\
\text { not against the } \\
\text { criteria of voters' } \\
\text { registry in } \\
\text { people's } \\
\text { sovereign states. }\end{array}$ & $\begin{array}{l}\text { "“'voters' } \\
\text { registry that } \\
\text { less reflect } \\
\text { the }\end{array}$ \\
\hline $\begin{array}{l}\text { Not } \\
\text { Currently } \\
\text { Revoked of }\end{array}$ & $\begin{array}{l}\text { Rights can only be implemented } \\
\text { when it is not against the law. } \\
\text { Annulment of rights can only be }\end{array}$ & $\begin{array}{l}\text { Is something } \\
\text { universal, and is } \\
\text { not against the }\end{array}$ & $\begin{array}{l}\text { constitutional } \\
\text { democracy" }\end{array}$ \\
\hline
\end{tabular}




\begin{tabular}{|c|c|c|}
\hline $\begin{array}{l}\text { Their } \\
\text { Voting } \\
\text { Rights; }\end{array}$ & $\begin{array}{l}\text { done by the court as judicial } \\
\text { institution that is allowed to give } \\
\text { injunction toward legal } \\
\text { implementation, including the rights } \\
\text { of the citizens and its annulment. } \\
\text { Thus, exception toward the citizens } \\
\text { that are already sentenced and } \\
\text { revoked their voting rights is } \\
\text { something based on the legal logic } \\
\text { and constitutional democracy. }\end{array}$ & $\begin{array}{l}\text { criteria of voters' } \\
\text { registry in } \\
\text { people's } \\
\text { sovereign states. }\end{array}$ \\
\hline $\begin{array}{l}\text { Listed in } \\
\text { Voters' } \\
\text { Registry; }\end{array}$ & $\begin{array}{l}\text { Each citizen has equal rights and } \\
\text { value in election process. Exempting } \\
\text { citizens from voting due to } \\
\text { administrative things is something } \\
\text { ridiculous, because it brings } \\
\text { possibility for neglecting the } \\
\text { substantive rights of the citizens. }\end{array}$ & $\begin{array}{l}\text { Regulation on } \\
\text { voters' registry } \\
\text { that exempted } \\
\text { individuals is } \\
\text { against the } \\
\text { universal rights } \\
\text { and fairness } \\
\text { value. }\end{array}$ \\
\hline
\end{tabular}

\section{b. Legal construction of voters' registry in 2009 general election}

In implementation of voters' registry in 2009 General Election, the requirements to be eligible to vote had been researched and stipulated by the Law No. 10 of 2006 on Establishment of Government Regulation to Substitute the Law No. 1 of 2006 on Second Amendment of Law No. 12 of 2003 on General Election of Members of National Parliament, Regional Representative, and Regional Members of Parliament; and General Election Committee (KPU)'s decision No. 11 of 2008 on steps to compile voters' registry for voters in foreign countries; KPU's decree No. 16 of 2009 on amendment of KPU's decree No. 10 of 2008 on steps to compile voters' registry for election of members of DPR, DPD, Provincial/City level DPRD; and KPU's Decree No. 17 of 2009 on amendment of steps to compile voters registry for voters in foreign country. In principle, the 2009 voters' registry did not have any significant change in its decrees to register voters. 
Analysis on the assessment toward the legal construction on voters' registry from the perspective of people's sovereignty in 2009's election can be seen in the following table:

\section{Table 3: Voters registry in 2009 election}

\begin{tabular}{|c|c|c|}
\hline $\begin{array}{l}\text { Voters' } \\
\text { Registry }\end{array}$ & Analysis & Notes \\
\hline $\begin{array}{l}\text { Indonesia } \\
\text { n Citizens }\end{array}$ & $\begin{array}{l}\text { Citizenship status considered as the criteria for } \\
\text { one to be eligible to vote is a general } \\
\text { requirement and is applicable in other } \\
\text { democratic states. }\end{array}$ & $\begin{array}{l}\text { Is something } \\
\text { universal, and is not } \\
\text { against the criteria of } \\
\text { voters' registry in a } \\
\text { people's sovereign } \\
\text { states. }\end{array}$ \\
\hline
\end{tabular}

\begin{tabular}{l|l} 
Age & Age limit and marriage status decided as the \\
17/Marrie & requirement to be eligible to vote is a general \\
d & and universally applicable. This requirement is a \\
& consideration of citizens' maturity to elect their \\
& leaders/representatives
\end{tabular}

Is

something

universal, and is not against the criteria of voters' registry in a people's sovereign states.

\begin{tabular}{l|l|l} 
People & Each citizen who are eligible to vote, also bear & Is
\end{tabular}
with responsibility for his/her choice. It would be universal, and is not undisturb hard to held mentally disabled person's against the criteria of ed accountable for what she/he has done. Thus, voters' registry in memory. exception for those with disturbed memory to people's sovereign vote is universally acceptable and it is also states. supported by legal logic.

Not Rights can only be implemented when it is not Currently against the law. Annulment of rights can only be Revoked done by the court as judicial institution that is of Their allowed to give injunction toward legal voters' registry in Voting implementation, including the rights of the people's sovereign Rights; citizens and its annulment. Thus, exception states. Conclusio n (1)

n

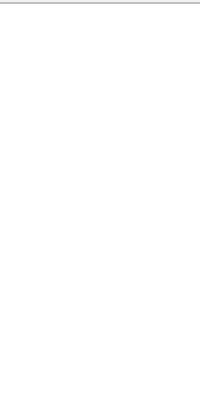


and revoked their voting rights is something

based on the legal logic and constitutional democracy.

Listed in Each citizen has the same rights and values in This rule on voters voters' the election process. Voters who are eligible to registry is not against registry is vote before the law is an action that respects and the voters registry not a must acknowledge the citizens' right that should be that upheld the upheld to attain the democratic and fair people sovereignty. community.

\section{c. Legal construction of voters' registry in 2014 general election}

In Law No. 42 od 2008 on Presidential and Vice Presidential Election that stipulates the voters' registry mentioned that those who are eligible to vote are Indonesian citizens aged 17 years old or more or have/had married (Article 27 Clause (1) Law, 2008) ${ }^{3}$ which is listed by the presidential and vice presidential election committee in voters' registry. In order to vote, voters should be registered (Article 28 Clause (1) Law, 2008). ${ }^{4}$

Law No. 8 of 2012 on General Election of Members of DPR, DPD, and DPRD mentioned in Article 1 Number 25, which stated that Voters are Indonesian Citizens who have reached the age of 17 or more or have/had married that listed as voters.

Fixe Voters Registry (DPT) definition stipulated in Article 1 Number 24 of KPU's decree No. 19 of 2014 is a registry of Indonesian citizens that are eligible as voters based on Law and are eligible to use their voting rights in Election Stations' (TPS) in President and Vice Presidential Election.

Conditions of voters in PKPU No. 19 of 2014 stipulated in details the Indonesian citizens that are eligible to vote. In details, the DPT is stipulated in Chapter II on Voters in PKPU No. 19 of 2014. Those who are eligible to vote in voting stations are (Article 6 KPU's Regulation No. 19, 2014) ${ }^{5}$ : 
a. Voters who are listed in Fixed Voters Registry (DPT) in the assigned voting stations (Model A.3 PPWP);

b. Voters who are listed in DPTb (Model A.4 PPWP);

c. Voters who are not listed in DPT and DPTb that consists of:

1) Special voters that listed in DPK (Model A PPWP);

2) Additional special voters listed in DPKTb (Model A.K PPWP).

Voters who are listed in DPTb are voters who due to certain conditions cannot vote in their assigned voting stations and give their vote in other voting stations TPS or TPSLN (voting stations in foreign countries) (Article 8 Clause (1) and Clause (2) and Clause (3) PKPU 19, 2014) ${ }^{6}$. Before voters use their voting rights, voters are required to report to their initial voting committee to get the Model A.5 PPWP form by showing their ID or another identity. Certain conditions mentioned PDTb consists of a) working on duties in the other area on the election date; b) currently hospitalized in hospital or other health clinics and the accompanying family member; c) currently serving the sentence in prison or correction center; d) on study assignment; e) changing address; and f) victims of the natural disaster.

The duties of the voters before the election are showing: (a) KTP or other identities; (b) Model A-5 PPWP form signed by the head of the election committee in the initial voting station (Article 8 Clause (8) PKPU No. 19, 2014). In the case where the voter could not report to the election committee where she/he would vote, but the voter himself/herself have had the Model a-5 PPWP form from the election station/PPS or PPLN, the voter can vote in the voting day that was later registered on the copy of DPTb by adding the name of the voter and the reason for his/her migration in the next line in the copy of that DPTb (Article 8 Clause (9) and Clause (10) PKPU 19, 2014), the voters had given the voters right to vote in that voting station/TPS from 07.00 am to $01.00 \mathrm{pm}$ local time (Article 8 Clause (9) and Clause (10) PKPU 19, 2014) .

For the voters that would vote in other TPS, but find it difficult to obtain Model A-5 PPWP from the initial PPS, then the voters can ask the Model A-5 PPWP from the $\mathrm{KPU} / \mathrm{KIP}$ in the district/city where she/he would go at least 10 days before the election 
(Article 9 Clause (1) PKPU No: 19, 2014). KPU/KIP in the district/city level through the sub-district election committee is mandated to ensure that the voter is listed in his initial place and ask the initial PPS to erase the voter from the DPT(Article 9 Clause (2) PKPU No: 19, 2014). A voter who had obtained the Model A-5 PPWP form reported to the intended KPPS where he/she would vote at least 3 days before the Election date (Article 9 Clause (3) PKPU No: 19, 2014).

Special voters listed in the DPK (Model PPWP) are voters that were not listed in DPT and DPTb that consisted of (Article 10 Clause (1) PKPU No: 19, 2014) :

a. Voters who have KTP or another identity; or

b. Voters who do not have KTP or another identity.

Voters' registry in 2014 general election is the voter's registry that was made to accommodate all the eligible citizens to have their rights. This is related to the Constitutional Court (MK) injunction No. 102/PUU-VII/2009, in 2009 that gave the freedom for the citizens to vote, as long as they have the KTP or another identity card, thus, each citizen can have and use their rights. However, this tended to be overly interpreted. Mentally disabled citizens were also allowed to use their voting rights in the Election, regardless to they could not hold accountable for their action, and this was beyond what is acceptable.

Analysis on the assessment of the legal construction on voters' registry from the perspective of people's sovereignty in 2014's election can be seen in the following table:

\section{Table 4: Voters registry in 2014 election}

\begin{tabular}{|c|c|c|c|}
\hline $\begin{array}{l}\text { Voters } \\
\text { Registry }\end{array}$ & Analysis & Notes & Conclusion \\
\hline $\begin{array}{l}\text { Indonesian } \\
\text { Citizens }\end{array}$ & $\begin{array}{l}\text { Citizenship status considered as the } \\
\text { criteria for one to be eligible to } \\
\text { vote is a general requirement and is } \\
\text { applicable in other democratic } \\
\text { states. }\end{array}$ & $\begin{array}{l}\text { Is something } \\
\text { universal, and is not } \\
\text { against the criteria } \\
\text { of voters' registry in } \\
\text { a people's sovereign } \\
\text { states. }\end{array}$ & "democratic \\
\hline
\end{tabular}




\begin{tabular}{|c|c|c|c|}
\hline $\begin{array}{l}\text { Age } \\
\text { 17/Married }\end{array}$ & $\begin{array}{l}\text { Age limit and marriage status } \\
\text { decided as the requirement to be } \\
\text { eligible to vote is a general and } \\
\text { universally applicable. This } \\
\text { requirement is a consideration of } \\
\text { citizens' maturity to elect their } \\
\text { leaders/representatives. }\end{array}$ & $\begin{array}{l}\text { Is something } \\
\text { universal, and is not } \\
\text { against the criteria } \\
\text { of voters' registry in } \\
\text { a people's sovereign } \\
\text { states. }\end{array}$ & $\begin{array}{l}\text { and based } \\
\text { on } \\
\text { constitution } \\
\text { voters' } \\
\text { registry" }\end{array}$ \\
\hline $\begin{array}{l}\text { Listed in } \\
\text { voters' } \\
\text { registry is } \\
\text { not a must. }\end{array}$ & $\begin{array}{l}\text { Each citizen has the same rights } \\
\text { and values in the election process. } \\
\text { Voters who are eligible to vote } \\
\text { before the law is an action that } \\
\text { respects and acknowledge the } \\
\text { citizens right that should be } \\
\text { upheld to attain the democratic and } \\
\text { fair community. }\end{array}$ & $\begin{array}{l}\text { This rule on voters } \\
\text { registry is not } \\
\text { against the voters } \\
\text { registry that upheld } \\
\text { the people } \\
\text { sovereignty. }\end{array}$ & \\
\hline
\end{tabular}

\section{E. CLOSING}

Voting rights is a constitutional right of the citizens. There is nothing that can negate it as long as it is not against the moral, religious, public stability and security values. An action to negate or deny the voting rights is a crime against constitutional democracy values. Because, democratic values are strongly upheld the citizens' rights, including their rights to vote. The correlation between voting rights and general election administration is a synergic relationship to create conducive and constitutional election. Administrative role should not be a barrier in upholding the constitutional democratic values, rather, it should be a filter to regulate and assist each citizen in using their voting rights, to give legal certainty both from technical aspects, that is from the accurate countdown of votes, and from the substantive aspect, that is to ensure the legal certainty in the implementation of accountable election.

Legal construction of voters' registry, in reality, is based on the level of legal development and political condition of each election time. Knowledge of who are eligible to vote and in what situation should the citizens obtain their voting rights is a knowledge and understanding of the state in election. Voters' registry after the 
Reformation era in 1999-2009 tend to stipulate the requirements for the citizens to be eligible to vote based on the values of people sovereignty as mandated in UUD 1945. Voters' registry for 2014 election has developed more freedom for the citizens to be eligible to vote. Any citizens who have reached the age of 17 or have/had married and can be proven by their identity, then the state would facilitate those citizens to vote, regardless whether the citizens are mentally disabled or not.

Voters' registry for the citizens who gave voting rights to those mentally disabled is a legal construction of voting registry who ignored the election quality. The consequence of rights is responsibility. Subsequently, it also applied to the citizens with mental disability, due to this disability, they cannot be held accountable for their action. Election is not merely an action of voting but also to bear the consequences of that choice. In legal perspective, especially in civil code, as mentioned in Article 44 Clause (2) person with mental disability cannot be sentenced, because their mental/minds are not healthy, thus, cannot be held responsible for his/her action. Meanwhile, in penal code, mentally disabled people are considered unfit to do a legal action. Therefore, voters' registry for those who are mentally disabled needs to be reviewed by the parties/institutions responsible for the implementation of General election (Government, KPU, and BAWASLU RI).

\section{BIBLIORGRAFI}

Barendt, Eric, An Introduction to Constitutional Law, (New York: Oxford University Press, 1998).

Budiarjo, Miriam, Dasar-Dasar Ilmu Politik Edisi Revisi, (Jakarta: Gramedia Pustaka Utama), 2008.

E Apter, David, The Politics of Modernization, University of Chicago. Penerjemahk: Sulistyo dan Wardah Hafidz. (Jakarta: PT. Gramedia), 1987.

Hart, H.L.A, Konsep Hukum, Cetakan ke V. Penerjemah: M. Khozim, (Bandung: Nusa Media), 2013.

International Institute for Democracy and Electoral Assistance (International IDEA), Standar-standar Internasional untuk Pemilihan Umum Pedoman Peninjauan Kembali Kerangka Hukum Pemilu. (Stockholm: International Institute for Democracy and Electoral Assistance), 2002.

Kelsen, Hans, Teori Hukum Murni, (Bandung: Nusa Media), 2013.

Mayers, and Harbison, Education, Manpower, and Economic Growth: Strategis of Human Resources Development (New York: McGraw Hill Books Co. Inc), 1964.

Nation, United, Human Rights Question and Answer. (New York: United Nations Department of Public Informations), 1993. 
Phillips, O. Hood, Constitutional and Administrative Law, 7th ed., (London: Sweet and Maxwell), 1987.

Purbopranoto, Kuntjoro, Hak-Hak Asasi Manusia dan Pancasila, (Jakarta: Pradnya Paramita), 1979.

Republik Indonesia, Badan Pengawas Pemilu, Pedoman Pengawasan Pemilu 2009. (Jakarta: Badan Pengawas Pemilu Republik Indonesia), 2009.

Republik Indonesia, Lembaga Administrasi Negara, Sistem Administrasi Negara Kesatuan Republik Indonesia Buku I Prinsip-Prinsip Penyelenggaraan Negara, (Jakarta: Lembaga Administrasi Negara), 2003.

Schmid, Von, Ahli-Ahli Pikir Besar Tentang Negara dan Hukum, Cetakan Keenam (Jakarta : PT. Pembangunan), 1988.

Strong, C.F, Modern political constitutions, (London: Sidwick and Jackson), 1972.

Thompson, Brian, Textbook on Constitutional and Administrative Law, edisi ke-3, (London: Blackstone Press ltd), 1997.

U.S. Department of State, Biro Program Informasi Internasional, Pemilu Amerika Serikat, Sebuah Paparan Singkat, 2012.

\section{Regulation:}

1945 The Constitution of The Republic of Indonesia

Law Number 3 of 1999 on The General Election

Law Number 4 of 2000 on The Amandement of Law Number 3 of 1999 on The General Election

Law Number 23 of 2003 on President and Vice President Election

Law Number 12 of 2003 on The DPR, DPRD, and DPD Election

The General Elections Commission Number 19 of 2014 on The Voting and Counting in The President and Vice President Elections

\section{Paper:}

Isra, Saldi, Keterangan Ahli Tertulis, DPKTb: Upaya Menyelamatkan Hak Pilih

Warga Negara. Keterangan disampaikan pada sidang DKPP dalam perkara

Pemilu presiden dan wakil presiden Tahun 2014, di Aula Kementerian Agama, 2014.

Republik Indonesia, Komnas HAM, Hasil Pemantauan dan Penyelidikan Hak

Konstitusional Warga Negara Dalam Pemilu 2014, yang disampaikan pada diskusi dengan DKPP, 15 Januari 2015, di Kantor DKPP, Jakarta.

Wiratraman, Herlambang Perdana, Konsesi Tanggung Jawab Negara dalam

Sistem ketatanegaraan Indonesia. Jurnal Hukum Yuridika Vol .20, No. I, Januari 2005

Putusan Mahkamah Konstitusi Republik Indonesia Nomor. 102/PUU-VII/2009 perihal pengujian Undang-Undang No. 42 Tahun 2008 tentang Pemilihan Umum Presiden dan Wakil Presiden.

International Covenant On Civil And Political Rights (ICCPR 1966) http://adminduk.kemendagri.go.id/detail/2013-tak-ada-lagi-ktp-ganda http://politik.news.viva.co.id/news/read/507686-puluhan-ribu-dpt-pilpres-2014masih-bermasalah, 